\title{
REVOCATION OF BUSINESS COMPETITION SUPERVISORY COMMISSION DECISIONS OVER CARTEL-RELATED CASES IN INDONESIA
}

\author{
Herwastoeti \\ Magister Ilmu Hukum, Universitas Muhammadiyah Malang, Indonesia \\ herwastoeti2021@umm.ac.id (corresponding)
}

\begin{abstract}
Business Competition Supervisory Commission (henceforth KPPU), a law enforcement body in Indonesia, was established based on Antimonopoly Law. This commission is a quasi-judicial body holding executorial authority over business competition-related cases. The crucial issue is apparent when business people submit petitions to the District Court since, from this point, different approaches and treatments between the KPPU and the District Court are revealed. This weak legal procedure, especially regarding the efforts made for petitions, is often seen as an opportunity by business people to stand against the decisions of the KPPU by submitting petitions to District Court, and several cartelrelated cases have been reinforced by Supreme Court. This research employed normative-juridical methods involving secondary data that were further analyzed by emphasizing juridical aspects for the analysis of the qualitative analysis method to present a description, from which a conclusion and recommendations were drawn. With it, decisions of the KPPU would not be labeled weak in law enforcement concerning business competition. Moreover, this approach is intended to deter business people regarding the violations of Law concerning Antimonopoly especially those regarding cartels which not only harm business people, but also the members of public in general.
\end{abstract}

Keywords: Revocation of decision; Cartel; KPPU.

\section{INTRODUCTION}

Fair business competitions set a positive atmosphere and trends in competitive businesses since they are intended to bring efficiency, productivity, and the quality of products resulting from these activities (Dwivedi et al., 2021; Serdyukov, 2017). With these trends, consumers could also gain benefits from fair business practices because of affordable prices and product quality improvement. On the other hand, when business practices are performed in unfair ways, it will potentially spoil the economy of the nation that is disadvantageous to the members of public.

The regulatory provisions regarding unfair business competition in Indonesia refer to law Number 5 of 1999 concerning Ban on Monopolistic Practices and Unfair Business Competition (henceforth Antimonopoly Law). Following the initiation of the economic globalization process in several countries between 1980 and 1990, several countries have adopted deregulatory, privatization, and free trade policies (Jusmadi, 2014). 
Law governing fair business competition is required in the ever-developing business world. Globalization is seemingly inextricable from the efficiency and competitiveness of businesses. Free market economy also demands highly competitive business practices in every single process. Competitions have been seen from the perspective believing that they are always profit-oriented and individualistic (Sirait, 2003). Unfortunately, this could potentially serve as the basis on which business people are encouraged to 'win the competition' either fairly or unfairly. Monopolistic practices and unfair business competition could unfairly hamper market mechanisms and the nation's economy.

Economic globalization and the initial establishment of the World Trade Organization (henceforth WTO) took place simultaneously. Several agreement terms were set forth in WTO regarding goods and services, including regulatory provisions highlighting how member countries could produce goods and services and trade and ensuring fair business competitions (Jusmadi, 2014).

A healthy business climate represents condition sine qua non that supports the market economy. Thus, Antimonopoly Law is a key requirement in a market economy. This law sets strict rules for business people and the economy to allow fair businesses and economic activities. Taking control over the market and gaining as many customers as possible are common objectives of business competitions, and this seems ideal, normal, and probably positive among businesses. However, to allow businesses to run appropriately and accordingly, unfair practices must be restricted or brought down to their lowest level to hamper unwanted consequences.

Antimonopoly Law seems to give a new hope since it protects business people from monopolistic practices and unfair business competitions (Zaid et al., 2021). Specific laws that embrace substantive and procedural law closely related to business competition law can set a new step for Indonesia in resolving business competition-related disputes for more efficient and effective business practices (Afrizal Mukti Wibowo, 2021; Ningrum et al., 2021; Yuliana Wahyuningtyas, 2019).

The commission, KPPU, is a law enforcement body specifically dealing with business competitions in Indonesia, established according to Antimonopoly Law. The KPPU, an independent body responsible to a President and separate from the government and other parties, is a quasi-judicial body authorized to deal with business competition cases (Nugroho, 2012).

Some weaknesses were studied regarding the role of KPPU as an implementer and supervisor over the enforcement of Law Number 5 of 1999 concerning Ban on Monopolistic Practices and Unfair Business Competitions (henceforth Antimonopoly Law). The KPPU, struggling to perform its tasks as a supervisor over business competitions, is deemed to violate the law. The burden of KPPU should be understandable recalling that the KPPU is newly born and has specific mechanisms. The KPPU as an independent regulatory body is given authority by Antimonopoly Law to set regulatory provisions to help enforce the law.

The problem is that these provisions could trigger different interpretations from what has been outlined in Antimonopoly Law. For example, Regulation of KPPU Number 1 of 2006 concerning Case Handling Procedures by KPPU extends the time for investigation, but this provision is not similar to what is provided in Antimonopoly Law. 
Petitions filed to the District Court always trigger different approaches and treatment between KPPU and District Court. This unreliable procedural law, especially regarding the efforts done to submit petitions, is seen as a chance by business people to support their stance against the decisions issued by the KPPU by submitting petitions to District Court. Departing from this issue, this research aims to delve into the revoked decisions regarding the mounting unfair business competition cases.

\section{RESEARCH PROBLEMS}

Departing from the above issue, this research aims to investigate why the decisions issued by Business Competition Supervisory Commission (KPPU) in cartel-related cases are often revoked at the court level?

\section{RESEARCH METHOD}

This research is conducted based on normative-juridical (doctrinal) methods (Soerjono Soekanto, 2018; Sonata, 2014), along with statutory, conceptual, and case approaches. In terms of its objectives, this research is explorative, aiming to study several legal issues in cartel cases happening in Indonesia.

The analysis techniques involved content analysis, requiring relevant secondary data, which were further qualitatively analyzed and systematically elaborated to allow easier understanding and analysis based on legal theories and rules in place.

\section{RESULTS AND DISCUSSION}

\section{Cartel Cases in Indonesia}

Article 30 of Law Number 5 of 1999 concerning Ban on Monopolistic Practices and Unfair Business Competition implies that KPPU is a body independent from interventions and authorities of the government and other parties. In executing its tasks, KPPU is directly responsible to the President. Despite this position, the KPPU remains independent from the interventions of public authorities, and, thus, report submission coming from KPPU is intended to comply with standardized administrative procedures.

According to Article 36 of Law Number 5 of 1999, the KPPU also holds authority as that of inquiries, general prosecutors, and courts. The KPPU is authorized to:

1. Receiving reports regarding violations of the law;

2. Conducting inquiries;

3. Conducting investigations by:

a. Summoning witnesses and business people allegedly committing violations

b. Delivering trial by hearing the information from witnesses and business people, and inspecting documents.

4. Delivering decisions and sending notification of the decisions issued by the KPPU to the business people concerned.

Antimonopoly Law also governs legal remedies as regulated in Article 44 and Article 45. Article 44 states that a business person could file a petition against District Court Decision 
within at least 14 days after the copy of the decision is received. At the district court, the petition files must be reviewed by judges within 14 days since the petition is received.

The district court is required to deliver a the within 30 (thirty) days since the petition is reviewed. An appeal against the decision of the district court to Supreme Court, according to Article 45 paragraph (3) of Law Number 5 of 1999, could also be filed, and it requires 30 days for Supreme Court to deliver the decision after an appeal is received (Article 45 paragraph (4) of Law Number 5 of 1999).

Cartel agreements are common in monopolistic practices. In a simple definition, a cartel is an agreement involving a business person and another intended to eliminate the competitiveness between the two. That is, cartel involves producers of certain products, and this practice is intended to control products, sales, and prices and to allow monopolistic practices against certain commodities or industries. Black's Law Dictionary defines cartels as " a combination of producer of any product joined together to control its productions, sale, and price, so as to obtain a monopoly and restrict competition in any particular industry or commodity."

Anton Muliono, in Kamus Besar Bahasa Indonesia, defines cartels as "(1) an organization of giant companies (states and so forth) producing similar products. (2) an agreement of companies intended to control certain commodity prices. Richard Postner defines cartels as: $A$ contract among competing seller to fix the price of product they sell (or, what is the small thing, to limit their output) is likely any other contract in the sense that the parties would not sign it unless they expected it to make them all better off.

Article 11 of Antimonopoly Law states that business people are prohibited to make an agreement with other businesses if this agreement is intended to affect the price and control production and/or market of products and/or services, which could lead to monopolistic practices and/or unfair business competitions.

Although no clear definition of cartels in Law concerning Ban on Monopolistic Practices as in Article 11, it can be assumed that a cartel is a horizontal agreement to affect price by controlling the production and/or market of products or services, sparking monopolistic practices and unfair business competition.

The agreement mentioned in Article 11 not only involves written terms but also unwritten ones as set forth in a contract. Terms of agreement between parties and obeyed by the parties are outlined in an agreement letter. Similarly, Article 1313 of Civil Law implies that an agreement is a condition where a person or more is bound to another person or more.

Law Number 5 of 1999 also provides provisions regarding the exception as in Article 50 to find out if an act is considered a violation or not, if something is categorized into an act or agreement, and if a sanction can be imposed on it or not according to Antimonopoly Law.

The exception of the provisions of Antimonopoly Law involves:

a. An act or an agreement intended to implement the regulatory provisions in the legislation in place;

b. An agreement regarding rights to intellectual property rights such as license, patent, trademark, copyright, industrial product design, integrated electronic circuit, trade secret, and agreements related to franchise; 
c. An agreement regulating technical standards of products and services not restricting or hampering competitions;

d. An agreement regarding agencies with no terms of agreement not including the provisions regarding obtaining supply chain of products or services with the price lower than what has been agreed upon;

e. An agreement regarding research intended to improve living standards of people in a wider scope;

f. An international agreement ratified by the government of the Republic of Indonesia;

g. An agreement or an act intended for export that does not interrupt the needs or supply chain of the domestic market;

h. Entrepreneurs categorized into small businesses; or

i. A cooperative that is specifically intended to give services to its members.

However, according to the legal dictionary of Economy ELILPS, cartels are defined as a conspiracy or a partnership among several similar producers aiming to control production, price, and sale, and to gain a monopolistic position. In other words, cartels are a monopolistic practice, where similar business people or producers work together to control production, determine price, and/or market regions of products and/or services to avert any competitions.

The concept of welfare state is principally developed in the context of market economy. The state's role in the concept of the welfare state according to Briggs is "...to modify the play of market force". Control and restrictions over the work of market force are important to help avert what is not expected, such as outcomes from what the market force may result in.

Goodin highlights some values that need to be kept in facing the free market: "The market has a 'corrosive effect' on values, debasing what was formerly precious and apart from mundane world, by allowing everything to be exchanged for everything else. In the end we are left with nothing but a 'vending machine society' where everything is available for a price.

In other words, market force without appropriate regulatory provisions will lead further to problems, affecting people as consumers and causing failure to realize market balance and quality from fair competition since it is all money-oriented. Thus, this situation can trigger risks when there is no clear and strict regulation serving as control over the market force.

From a different perspective, Sri Rejeki Hartono opines that the intervention of the state in economic activities represents one of the essential principles in the development of the concept of law based on national legal principles based on the perspective of the aspects of commercial and economic law. Economic activities require the intervention of the state, recalling that the main objective of the economy is to seek profits. This orientation seems to trigger distortion or unfair conducts that could harm certain parties or all.

Therefore, the intervention of the state in economic activities should be relevant to the interests of all parties since this intervention aims to maintain the balance of interests of all parties in society and to protect the interests of the producers, consumers, the state, and public interests over individual or corporate interests.

Cartels potentially spark unfair competitions that could put others in jeopardy. Cartels are usually performed by trade associations together with their members. The existence of these 
associations is positive. However, associations-related activities that are intended to control the price, will only restrict the practices of fair business competitions.

In most countries, cartels involve agreements among competitors to share markets, allocate customers, and implement prices. Cartels are seen as the most disadvantageous business collaboration since it is driven to control markets for their own profits.

Classically, cartels involve three factors: prices, production, and marketing regions. However, the losses could come from the monopolistic practices run by cartel players and, thus, in a small scope, it causes inefficiency in the allocation of financial resources. This is obvious in deadweight loss due to restriction of production that is usually performed by monopolistic companies to keep their price high while consumers will no longer have more options in terms of reasonable price, quality, and after-sale services.

An agreement like a cartel could minimize or entirely eliminate competitions, leaving customers with no choices but unreasonable prices. The impact could be harder when this strategy strikes drug stores. The absence of competitions due to cartels will force customers to face high prices and unreasonable choices. Drug prices may soar and access to health may become almost impossible. In such a case, people will be forced to buy things just because they have to, not because the price is affordable.

\section{From the Perspective of Theoretical Approach in the KPPU Decisions regarding Cartels}

\section{a. Balancing Theory}

This theory is more emphasized on seeing whether an action taken by market players tend to restrict or eliminate market competitions or promote competitions. This theory also takes into account social economic interests, including the interests of small business players.

\section{b. Per se Theoretical Approach}

This theory is also known as per se illegal. All per se prohibitions are clear, strict, and absolute in giving legal certainty for business people. This prohibition sees that the actions taken contravene the law. With this approach, petitioners no longer need to prove whether the impact of an agreement arranged by the competitor takes place.

Antimonopoly and unfair business competition law in several countries categorizes two factors into per se theoretical approach:

\section{1) Horizontal Price Fixing}

Horizontal price fixing is set by business players that produce or sell the same goods or services by raising, controlling, and fixing the prices of the goods or services. In the investigation of the case, the petitioners have the responsibility to prove whether price fixing has taken place.

\section{2) Group Boycotts or Exclusionary Provisions}

This approach represents the condition where two or more business people of one division or particular distribution make an agreement with their competitions, aiming not to provide goods or services for other certain business players. 


\section{c. Rule of Reason}

Rule of reason is the opposite of per se illegal. This approach implies that punishment imposed on the action allegedly violating the law concerning business competitions should take into account the situation and the condition of the case. Therefore, the alleged conduct should be looked at further to find out whether the conduct inappropriately restricts the competition. In such a case, a petitioner is required to show the consequences caused by the agreement, activities, and dominant control that may hamper competitions or cause losses.

The rule of reason requires evidence and evaluation of the impacts of agreement, activities, and certain dominant control to determine whether the agreement or the activities related to it limit the competition. The evidence should see to what extent anti-competition attitude has limited market competitions. Such conduct cannot be simply prohibited although the alleged action is proven. This approach allows courts to carry out interpretations regarding the law and market (Rokan, 2010).

\section{CONCLUSION}

Business people receiving the decisions from the KPPU always try their best to find a gap that allows them to file petitions to District Court. In this case, approaches and treatment from the KPPU and District Court are different, especially regarding the situation that the petitions are often intended to stand against the decisions of the KPPU. There have been several decisions delivered by the KPPU that were revoked at District Court and Supreme Court, putting business people in a winning position.

\section{REFERENCES}

Afrizal Mukti Wibowo. (2021). PERBANDINGAN HUKUM ARBITRASE DAN ALTERNATIF PENYELESAIAN SENGKETA ARBITRASE ONLINE INDONESIA DAN CINA. Audito Comparative Law Journal, 2(2), 110-118. https://ejournal.umm.ac.id/index.php/audito/article/view/16372/9349

Dwivedi, Y. K., Ismagilova, E., Hughes, D. L., Carlson, J., Filieri, R., Jacobson, J., Jain, V., Karjaluoto, H., Kefi, H., Krishen, A. S., Kumar, V., Rahman, M. M., Raman, R., Rauschnabel, P. A., Rowley, J., Salo, J., Tran, G. A., \& Wang, Y. (2021). Setting the future of digital and social media marketing research: Perspectives and research propositions. International Journal of Information Management, 59, 102168. https://doi.org/10.1016/J.IJINFOMGT.2020.102168

Jusmadi, R. (2014). Konsep Hukum Persaingan Usaha, Sejarah, Perdangan Bebas, dan Pengaturan Merger - Akuisis. Setara Press.

Ningrum, R. P., Arief, S., \& Herwastoeti. (2021). ANALISIS PUTUSAN MAHKAMAH

AGUNG NO.2871K/PDT/2017 DALAM KASUS PENGINGKARAN AKTA PERJANJIAN PERDAMAIAN NO.04/PDT.G/2000/PN.PROB. Indonesia Law Reform Journal, 1(1), 70-87. https://doi.org/10.22219/ILREJ.V1I1.16126

Nugroho, S. A. (2012). Hukum Persaingan Usaha di Indonesia Dalam Teori dan Praktik Serta Penerapan Hukumnya. Kencana Prenada Media Group.

Rokan, M. K. (2010). Hukum Persaingan Usaha. PT Raja Grafindo Persada.

Serdyukov, P. (2017). Innovation in education: what works, what doesn't, and what to do about 
it? Journal of Research in Innovative Teaching \&amp; Learning, 10(1), 4-33. https://doi.org/10.1108/JRIT-10-2016-0007

Sirait, N. N. (2003). Asosiasi dan Persaingan Usaha Tidak Sehat. Pustaka Bangsa Press.

Soerjono Soekanto. (2018). Penelitian Hukum Normatif: Suatu Tinjauan Singkat. In Rajawali Press. Rajawali Press.

Sonata, D. L. (2014). Metode Penelitian Hukum Normatif dan Empiris: Karakteristik Khas dari Metode Meneliti Hukum. Fiat Justisia Jurnal Ilmu Hukum, 8(1), 15-20. https://doi.org/10.25041/fiatjustisia.v8no1.283

Yuliana Wahyuningtyas, S. (2019). Competition and Regulation in Network Industries. 20(1), 33-53. https://doi.org/10.1177/1783591719834864

Zaid, Z., Dawaki, F. A., \& Ololade, S. K. (2021). Should the State Control Tariffs? Journal of Governance and Public Policy, 8(1), 22-36. https://doi.org/10.18196/JGPP.811340 